\title{
Pemberdayaan Masyarakat dan Kerjasama Masyarakat Swasta Mengatasi Masalah Stunting di Desa Lomuli-Kabupaten Pohuwato
}

\author{
Andi Juanna ${ }^{1}$, Rusli Isa ${ }^{2}$ \\ 1,2 Universitas Negeri Gorontalo, Jl. Jend. Sudirman No. 6 Dulalowo Timur, Kota Tengah, Kota \\ Gorontalo, IndonesiaFakultas Ekonomi, Universitas Negeri Gorontalo, Indonesia \\ Email: andijuanna@ung.ac.id, rusliisa@ung.ac.id
}

\begin{abstract}
ABSTRAK
Program Kuliah Kerja Nyata (KKN) Tematik periode II Universitas Negeri Gorontalo Mengusung tema besar mengenai Stunting, yang bertujuan untuk memberikan edukasi mengenai pentingnya menyaja kecukupan gizi khususnya bagi ibu hamik dan anak-anak. Objek pelaksanaan program ini berlokasi di Desa Lomuli Kecamatan Lemito Kabupaten Pohuwato. Kegiatan yang dilaksanakan saat pelaksanaan KKN diawali oleh kegiatan sosialisasi dan penyuluhan kesehatan bagi ibu hamil dan anak akan khususnya, dan masyarakat desa Lomuli umunya, dimana sebagai pelaksana kegiatan adalah mahasiswa, Dinas Kesehatan, serta Puskesmas Desa Lomuli. Kegiatan ini juga mengundang pihak swasta maupun individu dalam skema Public-Private Partnership (PPP) yang bertujuan untuk menagajak organisasi-organisasi tersebut untuk mengagendakan program penanggulangan Stunting sebagai program tahunannya. Luaran dari program ini adalah untuk membentuk kesadaran masyarakat serta pemerinta akan pentingnya menjaga kesehatan, dan pemberian vitamin bagi ibu hamil dan anak-anak, serta menjaga lingkungan yang sehat dan bersih untuk membentuk masyarakat yang sehat dan bersih.
\end{abstract}

Kata Kunci: Prevention of Stunting, dan public-private partnership

\begin{abstract}
Community Services Programme (KKN) Tematik Universitas Negeri Gorontalo $2^{\text {nd }}$ period 2020 has carried on a Stunting as a big theme, which aims to provide the education about importance of maintaining nutritional adequancy especially to women, pregnant mother, and children. The object of this programme held at Lomuli village District of Lemito, Regency of Pohuwato. The activities in this KKN programme started with an outreach and extention program which carried out by the health office, student, and Puskesmas of Lomuli village. Besides, students also invite private parties or social organization and individuals to enter and prioritize stunting program as their annual organizational agenda in a Public Provate Partnership (PPP). The outcome of this program is there are an awareness of community also the government about the importance of maintaining nutritional adequancy, and also the importance to protect an environment and lead a clean and healthy lifestyle.
\end{abstract}

Kata Kunci: Prevention of Stunting, dan public-private partnership

(C) 2021 Andi Juanna, Rusli Isa Under the license CC BY-SA 4.0

Correspondence author: Andi Juana, andijuanna@ung.ac.id, Gorontalo, Indonesia 


\section{PENDAHULUAN}

Sumber daya manusia yang unggul menjadi salah satu indikator keberhasilan dalam pencapaian tujuan pembangunan nasional, yang hal tersebut sangat relevan dengan tujuan pembangunan berkelanjutan (SDG's) sesuai dengan resolusi PBB dengan agenda transforming our world 2030, dengan rencana aksi global untuk melindungi dan membangun bumi dan seluruh manusia di dalamnya bersamaan dengan pembangunan kesejahteraan dan perdamaian bagi semua pada tahun 2030.

Salah satu tujuan dari SDG's adalah mencari solusi berkelanjutan untuk menghilangkan kelaparan dan segala bentuk malnutrisi pada tahun 2030 serta mencapai ketahanan pangan. Salah satu permasalahan yang paling menonjol terkait hal tersebut adalah stunting, dimana pemerintah masih berupaya untuk mempercepat eradikasi kelaparan, mencapai keamanan pangan dan gizi; dan peningkatan pertanian yang berkelanjutan. Pemerintah Indonesia melakukan pendekatan yang holistik untuk mencapai tujuan tersebut. Badan Perencanaan dan Pembangunan Nasional membuat formula integrasi melalui kerangka kerja multisektor. Dalam kerangka kerja ini, Kementerian Kesehatan memegang peranan utama untuk intervensi gizi spesifik, sedangkan kementerian teknis lainnya berperanan untuk intervensi gizi sensitif yang juga sebagai faktor pendukung (Development Initiative, 2018). Pahlevi (2012) menambahkan bahwa Faktor gizi memegang peranan penting dalam mencapai SDM berkualitas yaitu sehat, cerdas dan memiliki fisik yang tangguh serta produktif.

Secara global prevalensi stunting mencapai $22,9 \%$ atau 154,8 juta anak di bawah usia 5 tahun menderita stunting. Masalah stunting dialami oleh sebagian besar anak di Negara miskin dan berkembang seperti Indonesia. Prevalensi stunting yang terjadi di Afrika selatan sebesar 18,6 \%, di Ethiopia sebesar 26,4\%, di Nigeria (22.2\%). Sedangkan terdapat 6 juta di Amerika Latin dan karibia. Prevalensi di Asia seperti India (38,4\% 2015), Pakistan (45\% 2012), Bangladesh (36,1\% 2014), Malaysia (20,7\% 2016), Philipina, Thailand (10,5\% 2017) 6, Indonesia 30,8\% (Budiastutik, dan Rahfiludin, 2019).

Pemerintah melalui kementerian kesehatan merumuskan lima pilar terkait strategi nasional percepatan pencegahan stunting, yaitu: 1) komitmen 
dan visi kepemimpinan; 2) Kampanye nasional dan komunikasi perubahan perilaku; 3) Konvergensi, koordinasi, dan konsolidasi program pusat, daerah, dan desa; 4) Gizi dan ketahanan pangan; dan 5) Pemantauan dan evaluasi.

Pemberdayaan masyarakat diperlukan sebagai salah satu upaya pencegahan stunting. Pada tahun 2017 pemerintah telah meluncurkan program Rencana Aksi Nasional Penanganan stunting pada tingkat nasional, daerah terutama desa. Program ini diprioritaskan pada penanganan gizi spesifik dan sensitive pada 1000 hari pertama kehidupan sampai dengan anak usia 6 tahun. Stunting adalah masalah kurang gizi kronis yang disebabkan oleh kurangnya asupan gizi dalam waktu yang cukup lama, sehingga mengakibatkan gangguan pertumbuhan pada anak yakni tinggi badan anak lebih rendah atau pendek (kerdil) dari standar usianya (Laili dan Andriyani, 2019).

Pemberdayaan masyarakat dalam hal ini melibatkan petugas kesehatan di Puskesmas terkait, serta penyuluhan pada ibu rumah tangga akan pentingnya pemberian nutrisi bagi anak dan ibu hamil. Keterlibatan petugas kesehatan dengan para ibu dalam memberikan promosi nutrisi selama kehamilan, memberikan dampak antara lain terhadap pengetahuan ibu dan kesehatan ibu dan anak. Petugas kesehatan nantinya akan menjadi tim penyuluh dan tim siaga yang bekerja sama dengan mahasiswa KKN UNG jika terjadi indikasi malnutrisi pada anak.

Upaya lainnya yang dapat dilakukan dalam rangka pencegahan stunting di Kabupaten Pohuwato adalah dengan memaksimalkan kerja sama lintas sektoral dalam skema Public-Private Partnership (PPP). Sebagaimana dalam penelitian Prahastuti (2020), bahwa Public-Private Partnerships adalah cara modern untuk memfasilitasi sektor swasta untuk memenuhi kebutuhan atas infrastruktur publik. Tantangannya sekarang adalah memperluas komponen infrastruktur menjadi pembangunan sosial termasuk pembangunan kesehatan masyarakat. PPP tentunya berbeda dengan Corporate Social Responsibility (CSR) yang telah dikenal luas pengertiannya. Hal ini karena skema PPP memiliki elemen manfaat profit bagi pihak swasta yang terlibat. Kontribusi bisnis bisa dalam bentuk pendampingan dana, produk/barang dan layanan/jasa yang ada di dalam ruang lingkup bisnis masing-masing perusahaan. Sektor swasta 
yang dimaksud bukan hanya perusahaan (dunia usaha), tetapi juga lembaga filantrofi dan donor penyandang dana yang lebih berorientasi pada manfaat advokasi dan dukungan kebijakan untuk keberlanjutan dan replikasi program yang menghasilkan perubahan yang lebih luas dan lebih berdampak.

Dari penjelasan di atas, dapat disimpulkan bahwa penanganan stunting di Kabupaten Pohuwato membutuhkan perhatian yang lebih serius, dan salah satu upaya yang dapat dilakukan adalah melalui pemberdayaan masyarakat maupun petugas kesehatan, serta melalui skema public-private partnership yang bisa melibatkan seluruh elemen baik baik pemerintah, swasta, organisasi sosial, maupun individual.

\section{METODE PELAKSANAAN}

Operasional program KKN tematik terdiri dari 3 tahap yakni tahap persiapan dan pembekalan, tahap pelaksanaan dan rencana keberlanjutan program.

\section{a) Persiapan dan Pembekalan}

Persiapan dan Pembekalan dilakukan oleh mahasiswa, dosen dan kelompok sasaran.

1. Persiapan administrasi

Pelaksanaan kegiatan KKN tematik ini dimulai dari pemrograman mata kuliah KKN pada KRS Online, yang termasuk didalamnya segala bentuk administrasi yang harus dipenuhi mahasiswa.

2. Persiapan waktu

Mengingat waktu pelaksanaan KKN tematik 2020 ini dilaksanakan bersamaan dengan kegiatan perkuliahan sedangkan jangka waktu pelaksanaan selama dua bulan maka waktu pelaksanaannya dilakukan pada hari jumat, sabtu dan minggu selama 4 minggu perbulan. Dengan demikian frekuensi kegiatan per bulan adalah 12 hari kegiatan yang dilaksanakan selama 2 bulan

3. Persiapan pengetahuan dan keterampilan

Mahasiswa yang dipilih untuk melaksanakan kegiatan ini sebaiknya dikhususkan berasal dari mahasiswa Kesehatan Masyarakat, mahasiswa 
Manajemen, dan Mahasiswa Administrasi Publik. Mahasiswa diharapkan dapat mengaplikasikan pengetahuan yang telah diperoleh selama di kelas terutama yang berkaitan dengan sosialisasi penanganan Stunting, Kemitraan, Pengorganisasian dan Administrasi.

4. Persiapan sarana dan prasarana

Bersama-sama dengan dosen pembimbing lapangan menyiapkan tempat Persiapan oleh dosen pembimbing lapangan meliput :

1. Persiapan administrasi

Proses Pelaksanaan kegiatan KKN tematik 2020 ini dari sisi dosen pembimbing dimulai dari pengusulan proposal pengabdian secara online melalui website http://lpm.ung.ac.id. Usulan dari dosen ini akan diproses oleh bagian akademik Fakultas dan selanjutnya akan masuk ke tim LPM.

2. Persiapan pengetahuan dan ketrampilan

Dosen pelaksana kegiatan KKN tematik ini terdiri dari dosen jurusan Manajemen bidang keilmuan Manajemen dan Administrasi Publik. Kolaborasi dua keilmuan ini yang dibutuhkan untuk melaksanakan pengabdian dengan tema tersebut diatas sehingga bisa mendapatkan hasil yang maksimal.

3. Persiapan sarana dan prasarana

4. Bersama-sama dengan mahasiswa peserta KKN menyiapkan administrasi terkait pembentukan kelompok.

\section{b) Pelaksanaan}

Daerah yang akan menjadi mitra pendampingan mahasiswa peserta KKN tematik 2020 adalah Desa yang ditunjuk di Kabupaten Pohuwato. Dikarenakan penanganan stunting di daerah masih cukup minim, maka program yang dilakukan adalah penyululahan pada kader kesehatan dan ibu rumah tangga mengenai penanganan stunting, juga mengajak pemerintah, pihak swasta, organisasi masyarakat, dan induvidu berkepentingan lainnya dalam merumuskan program penanganan stunting di Kabupaten Pohuwato.

Metode yang digunakan dalam program penanganan Stunting adalah pemberdayaan kelompok swadaya masyarakat atau kader kesehatan. Kelompok ini akan berperan sebagai penyuluh kesehatan yang dibantu oleh 
petugas kesehatan yang kompeten, serta mahasiswa KKN. Metode lain yang akan dikembangkan adalah bagiamana membuat makanan olahan yang bersih dan sehat, serta mengajak pihak pemerintah dan swasta dalam bagian dari Public-Private Partnership (PPP) dalam menangani permasalahan Stunting di Kabupaten Pohuwato.

Adapun langkah operasional untuk mengatasi permasalahan adalah:

1. Pengadaan beberapa alat dan bahan penunjang operasional

2. Pembentukan kelompok swadaya masyarakat/ kader kesehatan

3. Mengadakan kerja sama dengan pihak pemerintah, swasta, dan organisasi masyarakat lainnya dalam skema public-private partnership.

Kegiatan yang akan dilaksanakan oleh mahasiswa dihitung dengan menggunakan jam kerja efektif mahasiswa dalam sebulan. Uraian tabel bentuk kegiatan dan jumlah mahasiswa adalah:

Tabel 2. Uraian kegiatan dan volume dalam 2 bulan

\begin{tabular}{|c|l|c|c|c|}
\hline No & \multicolumn{1}{|c|}{ Nama Pekerjaan } & Program & $\begin{array}{c}\text { Volume } \\
\text { (JKM) }\end{array}$ & Keterangan \\
\hline 1 & $\begin{array}{l}\text { Sosialisasi } \\
\text { penanganan Stunting }\end{array}$ & $\begin{array}{c}\text { Proses } \\
\text { persiapan alat } \\
\text { presentasi }\end{array}$ & 2160 & $\begin{array}{c}7 \text { orang } \\
\text { mahasiswa }\end{array}$ \\
\hline 2 & $\begin{array}{l}\text { Pembentukan KSM/ } \\
\text { kader Kesehatan }\end{array}$ & $\begin{array}{c}\text { Proses } \\
\text { administrasi }\end{array}$ & 2160 & $\begin{array}{c}8 \text { orang } \\
\text { mahasiswa }\end{array}$ \\
\hline 3 & $\begin{array}{l}\text { Kerja sama melalui } \\
\text { skema public-private } \\
\text { partnership }\end{array}$ & $\begin{array}{c}\text { Proses } \\
\text { administrasi }\end{array}$ & 2160 & $\begin{array}{c}7 \text { orang } \\
\text { mahasiswa }\end{array}$ \\
\hline 4 & $\begin{array}{l}\text { Penyuluhan bagi ibu } \\
\text { rumah tangga }\end{array}$ & $\begin{array}{c}\text { Proses } \\
\text { operasional }\end{array}$ & 2160 & $\begin{array}{c}8 \text { orang } \\
\text { mahasiswa }\end{array}$ \\
\hline Total Volume Kegiatan & & 8640 & $\begin{array}{c}30 \\
\text { mahasiswa }\end{array}$ \\
\hline
\end{tabular}

\section{HASIL DAN PEMBAHASAN}

Lomuli adalah sebuah desa yang terletak di kecamatan Lemito, Kabupaten Pohuwato, Provinsi Gorontalo , Asal usul desa ini bermula dari beberapa dusun yang ada di desa lemito yakni dusun lomuli. Seiring berjalannya waktu, pada tahun 1985 menjadi desa persiapan menuju wilayah otonomi baru nanti pada tahun 1986 di tetapkan sebagai definitive atau desa pemekaran. Dalam arus perjuangan pemekaran tak lupuk kita jumpai beberapa tokoh sebagai pemrakarsa di antaranya bapak Abdullah lai, harun doholio, dan 
bapak akuba latif. Nama desa ini terinspirasi dari sebuah tumbuhan dimana menurut masyarakat setempat bahwa itu adalah tumbuhan lomuli. Tumbuhan ini sangat banyak di temukan atau tumbuh di desa lomuli khasiat atau manfaatnya pun banyak, salah satunya di pergunakan sebagai bahan pembuat anyaman tikar sehingga berdasarkan hal itu desa ini di cetuskan sebagai desa Iomuli.

\section{Persiapan Kegiatan KKN Tematik Desa Lomuli Kecamatan Lemito}

Dengan mengetahui potensi desa baik secara kuantitatif maupun kualitatif, mahasiswa akan dapat menganalisis kebutuhan-kebutuhan apa saja yang dapat dilaksanakan di Desa Lomuli khususnya yang menyangkut permasalahan Stunting, disamping itu kegiatan-kegiatan lain yang dapat menjadi kegiatan tambahan untuk menunjang kegiatan utama. Untuk itu diperlukan persiapan-persiapan untuk mendapatkan hasil seperti yang diharapkan.

Kegiatan KKN Tematik periode II mahasiswa Universitas Negeri Gorontalo di Desa Lomuli Kecamatan Lemito Kabhpaten Pohuwato diawali dengan persiapan kegiatan yang dilakukan oleh dosen pembimbing dan mahasiswa peserta KKN Tematik dalam bentuk coaching yang dilaksanakan pada tanggal 1 September 2020, yang bertempat di Ruang Kuliah Manajemen Fakultas Ekonomi.

Persiapan kegiatan dalam coaching fokus pada pembahasan kegiatankegiatan yang akan dilakukan oleh mahasiswa yang tidak terlepas dari program utama KKN Tematik yakni Pemberdayaan Masyarakat dan Public-Private Partnership Dalam Mengatasi Permasalahan Stunting Di Kabupaten Pohuwato, dimana dalam persiapannya fokus mahasiswa adalah dengan menjalin koordinasi dengan pihakdinas terkait dan puskesmas serta pihak pemerintah desa dalam membangun kebersamaan dengan mahasiswa melaksanakan program penyuluhan kesehatan masyarakat dan membuat masyarakat sadar akan menjaga kesehatan dan menjaga lingkungan yang sehat dan bersih sebagai bagian pencegahan dalam permasalahan stunting. 


\section{Pelaksanaan Kegiatan KKN Tematik Desa Lomuli Kecamatan Lemito}

Kegiatan KKN Tematik mahasiswa difokuskan bertempat di Desa Lomuli Kecamatan Lemito Kabupaten Pohuwato, dimana setelah mahasiswa dibekali pemahaman mengenai program yang akan dilaksanakan, maka selanjutnya mahasiswa dipersiapkan untuk berangkat ke desa tujuan, melaksanakan program-program pengabdian yang fokus pada penanganan dan pencegahan Stunting sampai pada mahasisswa kembali ke kampus. Adapun programprogram yang dilaksanakan oleh mahasiswa adalah:

\section{Penerimaan oleh Desa}

Kegiatan ini dilaksanakan tepat setelah mahasiswa sampai di Kantor Desa Lomuli Kecamatan Lemito. Mahasiswa yang datang langsung disambut oleh Kepala Desa beserta jajarannya, serta menunjukkan lokasi tempat $\mathrm{t}$

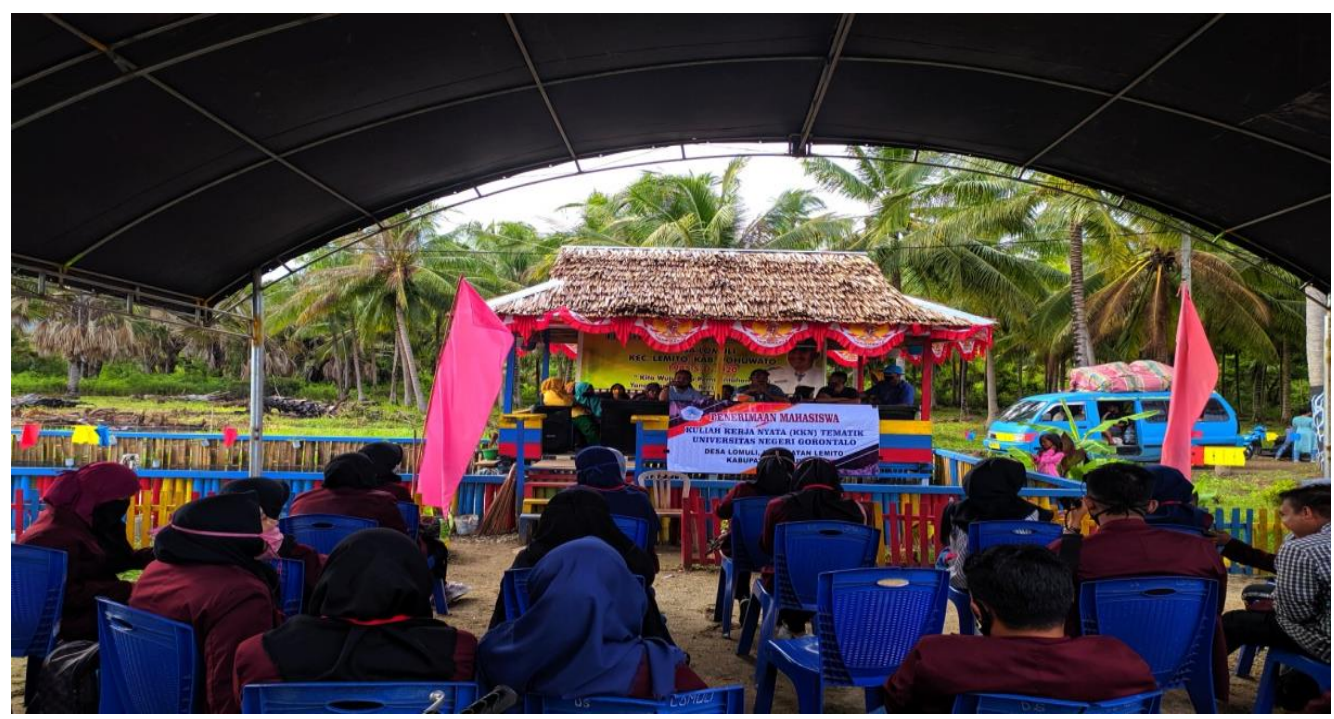

asiswa selama berada di lokasi KKN Tematik.

Dokumentasi: Mahasiswa dan DPL saat diterima Kepala Desa Lomuli dan jajarannya

2. Observasi masyarakat

Tahapan pertama yang dilakukan adalah tahap observasi. Kegiatan ini dimaksudkan untuk mengobservasi keadaan masyarakat terkhusus ibu dan anak untuk mengetahui program pemerintah dalam mengatasi 
stunting, sekaligus mensosialisasikan kegiatan mahasiswa yang berkaitan dengan penanggulangan stunting.

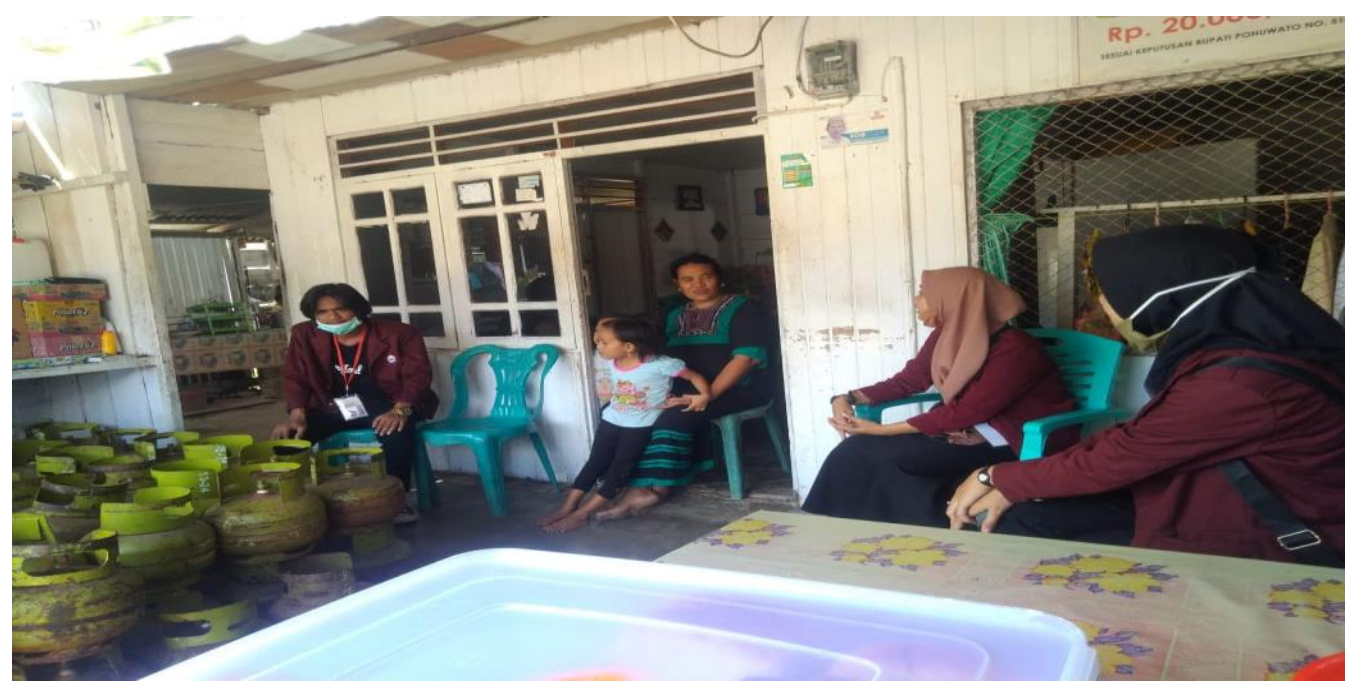

3. Penyuluhan kesehatan masyarakat

Kegiatan ini dilaksanakan pada tanggaal 16 September 2020, yang berlokasi di Kantor Desa Lomuli. Kegiatan ini bekerja sama dengan dinas kesehatan dan puskesmas setempat, yang bertujuan untuk memberikan pengetahunan dan sosialisasi kepada masyarakat akan pentingnya menjaga kesehatan, dan menjaga asupan nutrisi bagi ibu dan anak.

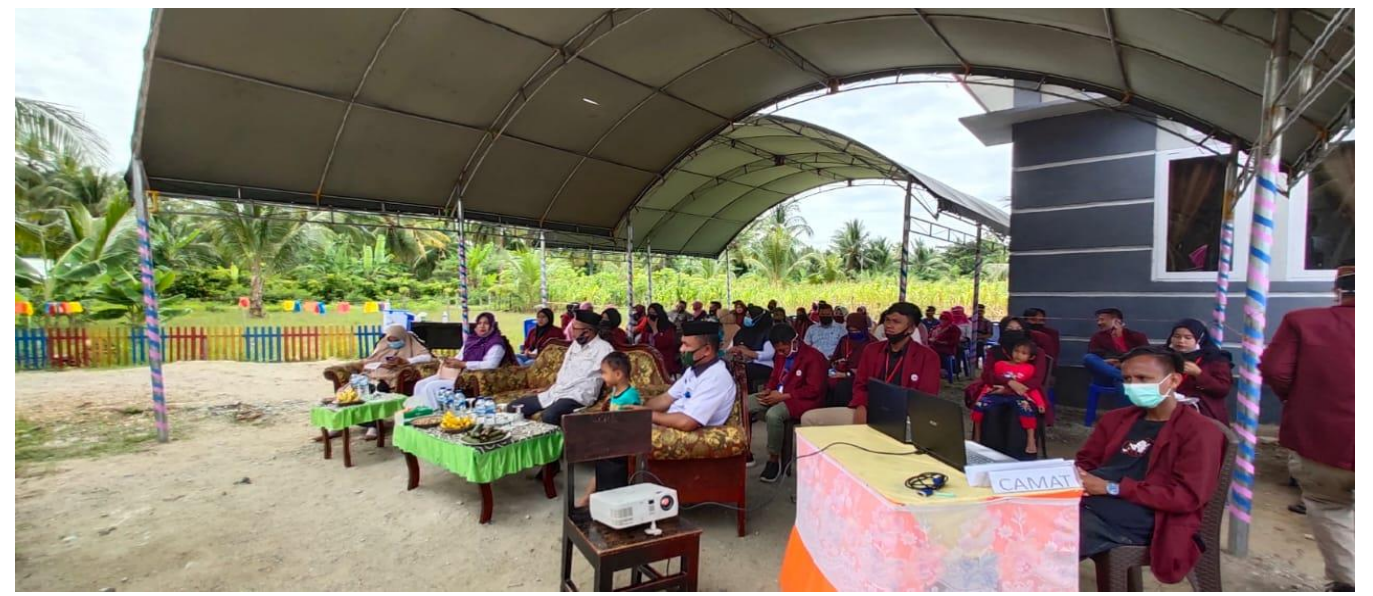

Dokumentasi: Kegiatan penyuluhan kesehatan masyarakat Desa Lomuli bersama Puskesmas

4. Pembentukan kader kesehatan

Kegiatan ini merupakan tindak lanjut dari kegiatan penyuluhan kesehatan masyarakat, dimana mahasiswa bersama pemerintah desa dan 
masyarakat mendeklarasikan masyarakat sadar stunting untuk Desa Lomuli, sekaligus membentuk kader kesehatan desa.

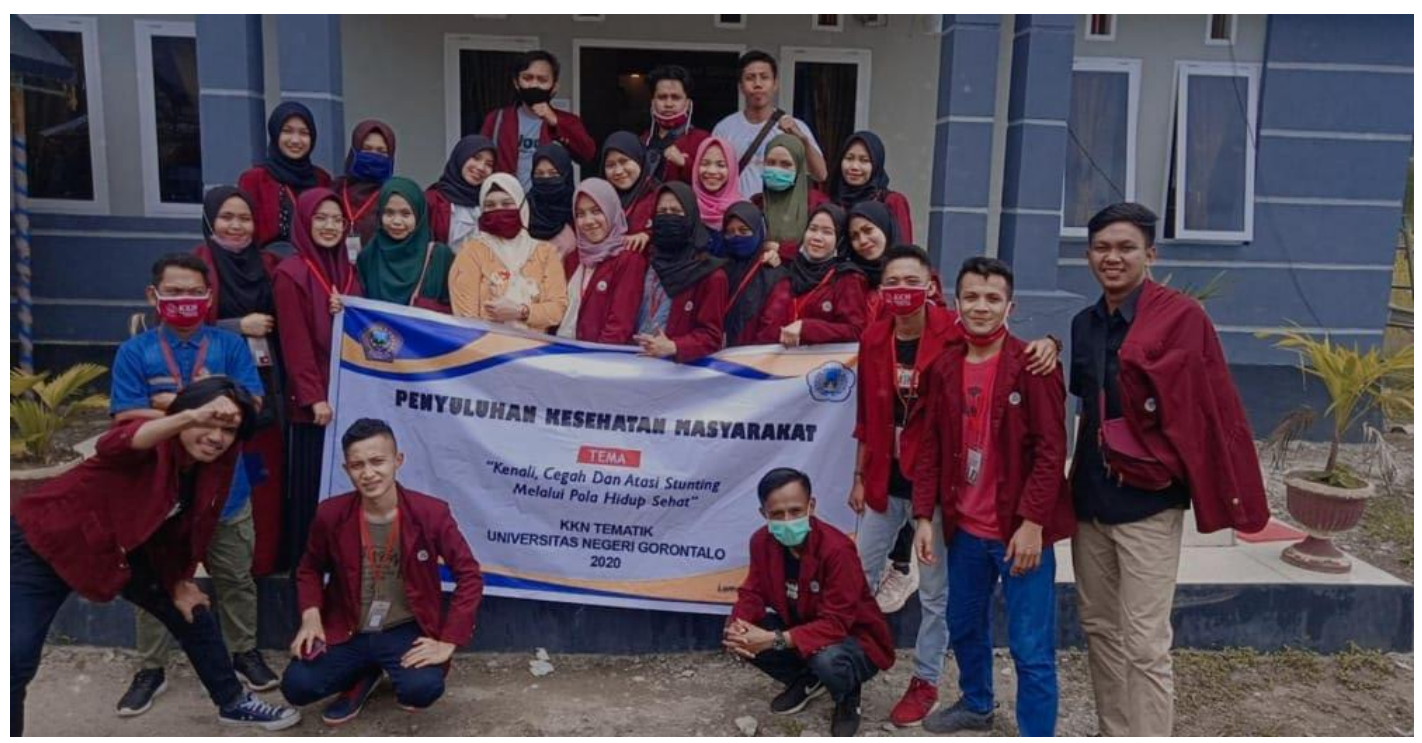

Dokumentasi: Sela kegiatan penyuluhan dan pembentukan kader kesehatan

5. Aksi Gizi

Kegiatan ini sebagai lanjutan dari kegiatan penyuluhan pada masyarakat, ddimana mahasiswa dibantu oleh dinas terkait mengunjungi rumah-rumah penduduk dan memberikan penjelasan tentang nutrisi yang tepat untuk menjaga metabolisme khususnya pada ibu dan anak. Kegiatan ini juga disertai dengan pemberian vitamin bagi ibu hamil dan anak.

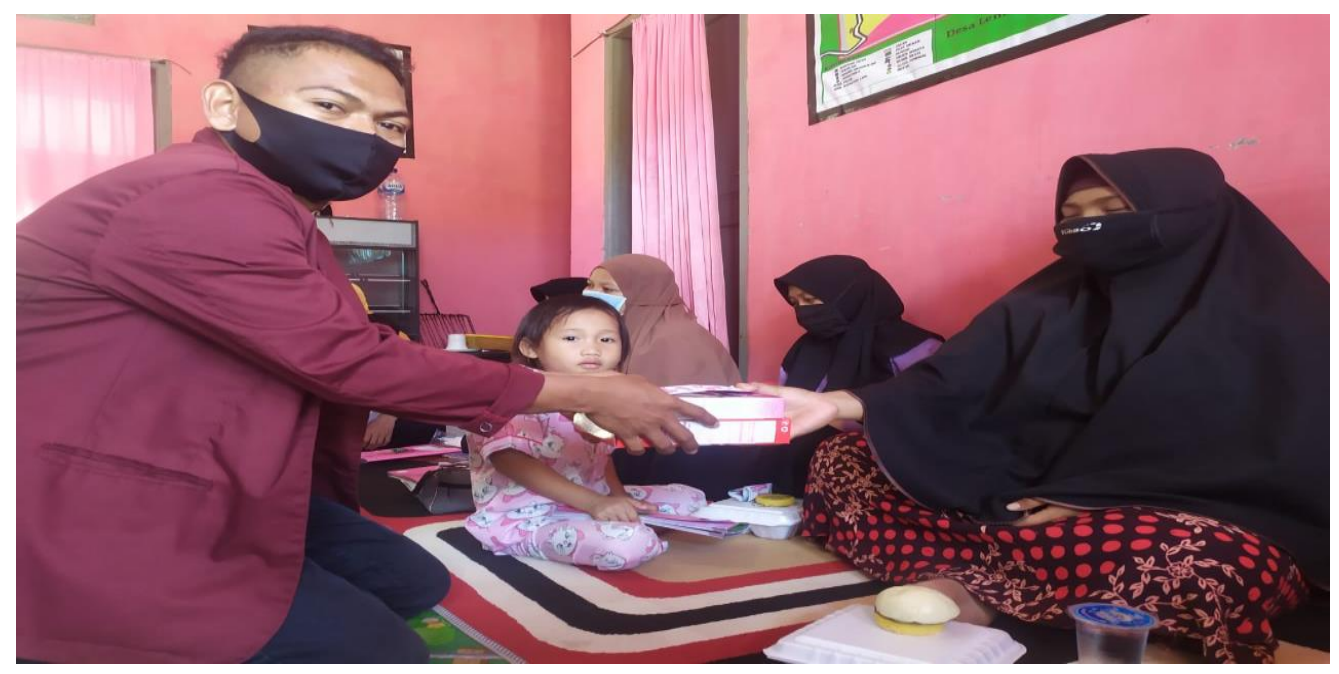

Dokumentasi: Pemberian vitamin bagi ibu, ibu hamil, dan anak-anak

6. Kegiatan Jumat bersih dan jalan sehat 
Kegiatan ini dilakukan dengan tujuan untuk menciptakan lingkungan masyarkaat yang bersih dan sehat, baik jasmani maupun rohani, sekaligus sebagai ajang silaturahmi dan membentuk hubungan yang harmonis antar mahasiswa dan masyarakat desa Lomuli. Kegiatan ini dimulai pada tanggal 11 september 2020, sampai dengan mahasiswa ditarik kembali ke

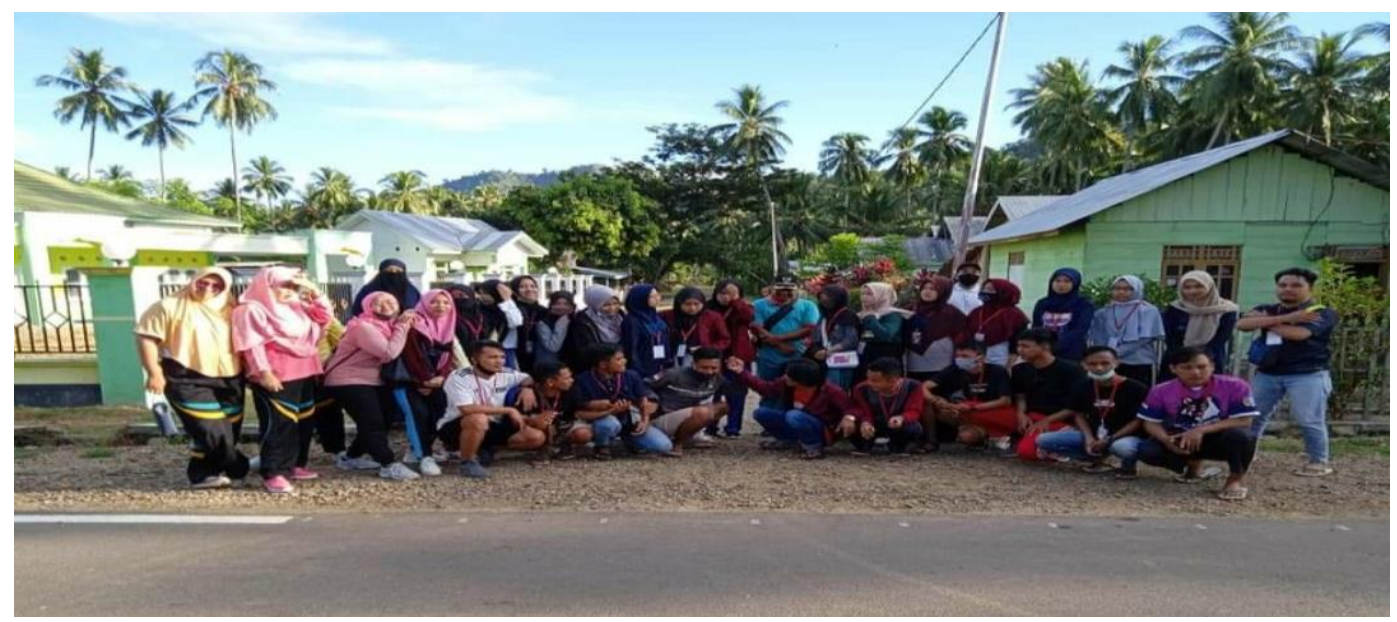

Dokumentasi: Kegiatan Jum'at bersih dan jalan sehat

7. Pembuatan Batas Desa

Kegiatan ini dilaksanakan dengan bekerja sama dengan jajaran pemerintah Desa Lomuli, yang bertujuan untuk membangun batas Desa Lomuli dengan Desa tetangga. Disamping itu juga membuat petunjuk arah antara dusun satu dengan dusun lainnya.

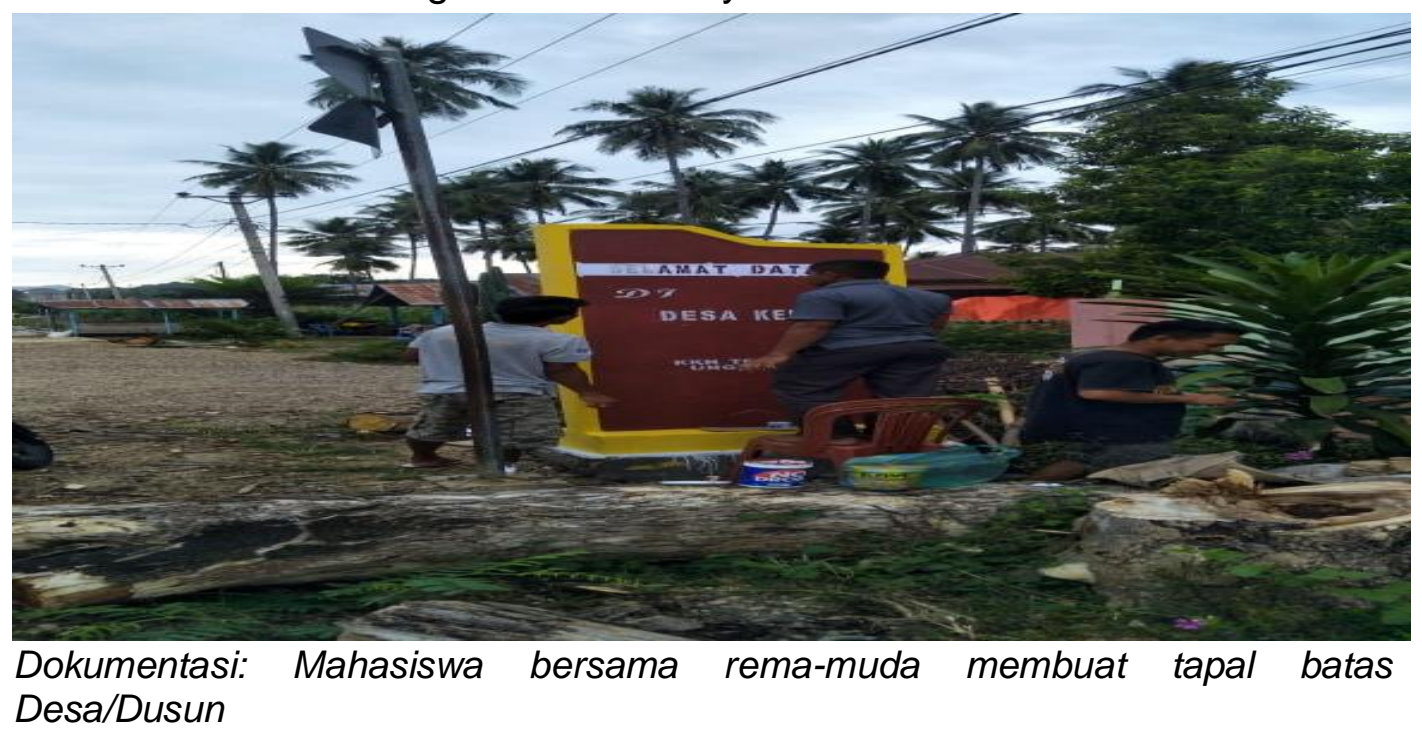

8. OSEAN (Olahraga, Kesenian, dan Keagamaan) dan Ramah/tamah 
Kegiatan ini dilaksanakan sebagai kegiatan penutup kegiatan-kegiatan yang telah dilakukan oleh mahasiswa selama dilokasi. Kegiatan ini dilaksanakan pada tanggal 1 oktober 2020, dan ditutup pada tanggal 12 oktober 2020.

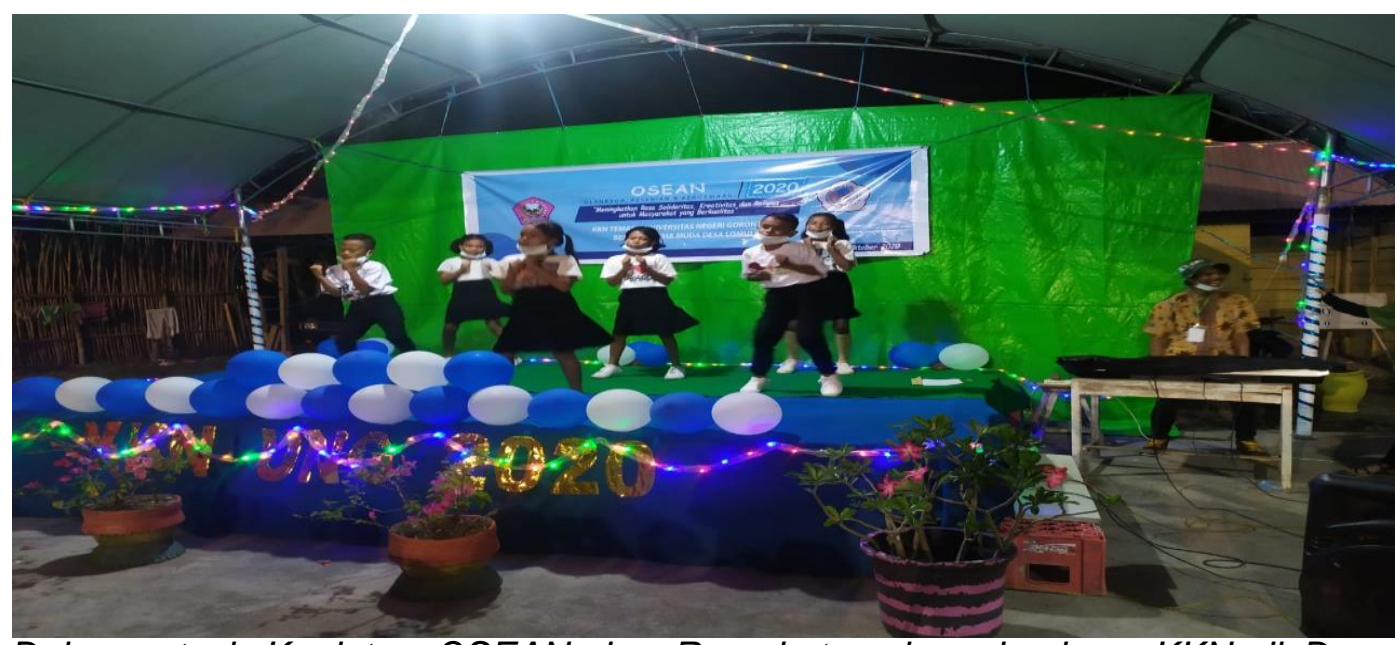

Dokumentasi: Kegiatan OSEAN dan Ramah tamah mahasiswa KKN di Desa Lomuli

\section{KESIMPULAN}

Pelaksanaan KKN Tematik dengan program Pemberdayaan masyarakat dan Public-Private Partnership di Desa Lomuli Kecatmatan Lemito Kabupaten Pohuwato merupakan kegiatan yang sangat baik untuk dilaksanakan secara berkelanjutan. Kegiatan pengabdian ini sangat penting karena sesuai dengan tujuan pembangunan nasional dan memberikan dampak jangka panjang untuk membentuk masyarakat yang sehat dan sadar stunting. Disamping itu, kegiatan pengabdian ini dapat menumbuhkan kesadaran masayarakat untuk saling menjaga satu sama lain, memiliki perilaku hidup sehat, dan pentingnya dalam memahami penyuluhan-penyuluhan yang diberikan oleh dinas-dinas terkait. Selain itu, juga dapat menumbuhkan kesadara antar organisasi yang ada di masyarakat baik itu Pemerintah Desa, Dinas Kesehatan, Puskesmas, dan organisasi masyarakat lainnya agar memasukkan program pencegahan dan penanganan stunting sebagai salah satu program yang diusung setiap tahunnya.

Kegiatan ini memerlukan dukungan dari pihak terkait, seperti pemerintah khusunya Kabupaten Pohuwato dalam mensosialisasikan Program pencegahan 
dan penangahan stunting, sehingga seluruh masyarakat dapat mengubah cara pandang pikiran, sikap, dan perilaku agar berorientasi pada kebiasaan hidup sehat, dan mendengarkan program-progra kesehatan dari dinas-dins terkait. Selanjutnya agar kegiatan ini dapat dilaksanakan secara berkisinambungan agar perubahan yang terjadi dimasyarakat dapat terpelihara.

\section{UCAPAN TERIMA KASIH}

Ucapan terima kasih disampaikan kepada;

1. Universitas Negeri Gorontalo atas dukungan dana sehingga program pengabdian ini bisa terlaksana.

2. Pemerintah Desa Lomuli Kecamatan Lemito yang telah berkenan sebagai mitra dan telah memfasilitasi pelaksanaan kegiatan ini.

\section{REFERENSI}

Pahlevi AE. Determinan Status Gizi Pada Siswa Sekolah Dasar. Jurnal Kesehatan Masyarakat. 2012;2:122-6.

Development Initiatives. Global Nutrition Report 2018: Nourishing the SDGs. Bristol, UK.2019

Budiastutik dan Rahfiludin. 2019. Faktor Risiko Stunting pada anak di Negara Berkembang Risk Factors of Child Stunting in Developing Countries. 122-126. https://doi.org/10.2473

Laili dan Andriani, Ratna Ariesta Dwi. 2019. Pemberdayaan Masyarakat Dalam

Pencegahan Stunting. Jurnal Pengabdian Masyarakat Ipteks Vol. 5 No.1 Prahastuti, Brian Sri. 2020. Kajian Kebijakan: Kemitraan Publik Swasta Penanggulangan Stunting Di Indonesia Dalam Kerangka Tujuan Pembangunan Berkelanjutan. Jurnal IImiah Kesehatan Vol 12 (1) 